\title{
Action Learning in Business Education: Goals, I mpact, and Global Perspectives
}

\author{
COREY SEEMAN
}

University of Michigan, Ann Arbor, Michigan, United States

\section{Action Learning Conference \\ Ross School of Business, University of Michigan June 3 to 5,2015 \\ https://michiganross.umich.edu/AL-Conference}

\section{Action Learning Curriculum}

The Ross School of Business at the University of Michigan, familiarly known as Michigan Ross, has long incorporated action learning (or experiential learning) as a key element in its curriculum. The keystone action learning program at Michigan Ross is Multidisciplinary Action Projects (MAP), which was first launched in 1992. In these projects, teams of students work on real-world problems with a corporate, start-up, nonprofit, or governmental partner. The program is unique at Michigan Ross because it is required for all MBA students. While the school is working on expanding those experiences to other degree programs, many other universities are incorporating action learning programs into their curriculum. Michigan Ross is now approaching its 25th anniversary in delivering students action learning opportunities, and the school recently hosted an academic conference that brought together schools with similar programs to discuss best practices, learning outcomes, student reflections, and new opportunities in this important space. In addition to faculty and staff at Michigan Ross, nearly 30 universities were represented, including University of Chicago, Massachusetts Institute of Technology, Carnegie Mellon University, Dartmouth College, University of Southern California, University of Maryland, University of Texas at Austin, and others.

As the environment changes dramatically for academic business libraries, there is a tremendous opportunity in supporting action learning at our business schools. Over and over again during the conference, the issue of supporting action learning revolved around the information needs of the students. Instead of working through cases, where the relevant and needed data is prepared for the student and bundled in one neat package, action learning projects force students to find data on their own, or (as we do at Kresge Library) with the assistance of a librarian. The librarians at Kresge Library Services at Michigan Ross have been supporting action learning through an embedded approach (Berdish \& Seeman, 2010, p.208-224; 2012, p.153-164). Many business libraries are supporting similar programs across the academic spectrum, including ones that require international travel (Juricek, 2013, p.123-126). Kresge Library assigns a librarian to work with each action learning team in all

Corey Seeman is the director of Kresge Library Services at the Ross School of Business, University of Michigan, Ann Arbor, cseeman@,umich.edu. 
Ticker: The Academic Business Librarianship Review, 1:1 (2015)

(C) 2015 Corey Seeman

programs at the school. Over the course of a calendar year, the librarians at Kresge support more than 300 teams in action learning programs. This has been an incredible "value added" that Kresge has provided to Michigan Ross. More proactively supporting these types of programs might be a very important element in the future of business librarianship in the academic endeavor.

\section{Opening Sessions}

The hosts of the conference were Valerie Suslow and Jim Walsh, both at Michigan Ross and heavily invested in the MAP program. Suslow, the senior associate dean for MBA Programs, has been a key administrator in the operation of MAP for a number of years. Walsch, a prominent professor at the school, has been a longtime faculty advisor for MAP.

The opening keynote was delivered by Anjali Sastry, senior lecturer at the Sloan School of Management, Massachusetts Institute of Technology. In her talk, "Lessons from the Front Lines of Action Learning and Teaching," Sastry focused on the opportunities that students have when learning in an environment where failure is an option. She used the phrase "fail better" from playwright Samuel Beckett to articulate the need for students in action learning projects to think creatively and entrepreneurially. This is more possible through unstructured action learning projects rather than through cases, which typically have more clear-cut solutions.

Melissa Peet, director of integrative learning and knowledge management, led the attendees in a group exercise: "Developing Goals for Action Learning." The session did a great job of differentiating between disembodied and embodied cognition. In action learning, the experiences are more embodied than in cases, creating, as Peet argued, opportunities for more long-lasting impact for the students. The exercise focused on creating embodied learning goals that were clear and measurable for students in these programs.

In a concurrent session, Jennifer Johnson, associate dean of undergraduate and integrated programs at Weatherhead School of Management, Case Western Reserve University, and Sam Miller, director of the Gigot Center for Entrepreneurship at Mendoza College of Business, University of Notre Dame, showcased the ways that their two institutions craft action learning experiences for undergraduate students in their colleges of business. Many of the topics revolved around corporate relations, especially in the context of projects that were physically closer to the school. Additionally, the discussion revolved around how to balance these courses with the rest of their course load, as these programs take place simultaneously with other classes. Both of these presentations outlined how the students are expected to address and resolve ambiguous questions that businesses face every day. They also showcased the need to ground the students in current writing on their fields and industries while making personal connections with thought leaders to track "future thinking" that will help them craft an appropriate solution for their sponsor.

Paul Danos, dean of the Tuck School of Business at Dartmouth College, spoke during the luncheon keynote on "The Role of Action Learning in Future Business School Curricula." His talk touched on his role at Michigan Ross during the launch of MAP in the early 1990s and addressed looking beyond our current modes of working with students to consider a 
Ticker: The Academic Business Librarianship Review, 1:1 (2015)

\section{(C) 2015 Corey Seeman}

future state of business education. He

projected that the MBA will evolve during the next 20 years to fundamentally change how the curriculum is delivered. He predicted the role of action learning to increase as students request and demand more experiential learning. He also expected that the "flipped classroom" will have a larger impact in business schools, as it will likely provide a more engaging and impactful way for students to learn and experience the key issues businesses face. One of the most relevant and powerful thoughts that he delivered was that the time spent on campus for MBA students will shrink, especially as technology enables the delivery of many courses. Time on campus will be focused on those classes where participation and teamwork are truly needed. This changing dynamic will have a huge impact on academic libraries in the next 20 years.

Lori Breslow, director at MIT Teaching \& Learning Laboratory, and Scott DeRue, associate dean of executive education at Michigan Ross, talked about assessment in action learning and the challenges that the format provides. Breslow focused on Intended Learning Outcomes (ILOs) and the enhanced value in business and other classes at MIT that have an engaged or flipped orientation. DeRue focused on surveys that he conducted with Ross MBA students as they worked through MAP. He also discussed the role of narrativebased reflection and the difference between real assessment and customer satisfaction. Both of these talks provided excellent coverage of the difficulties in assessing learning outcomes when there is great variance in the projects.

Gretchen Spreitzer, professor at Michigan Ross, led the group in interactive discussions about faculty selection, development, and feedback in field projects. It was a common experience from all of the schools represented that not all faculty participate in actionlearning. The discussions focused on engaging faculty at the school to ensure that the learning objectives are being met. This is especially true when working with new faculty on these programs.

\section{Closing Sessions}

On the last day of the meeting, two sessions showcased the student and corporate sponsor experiences and what constitutes best practices in building successful programs. The first session, "Building High-Quality Relationships with Businesses and Partner Organizations," was moderated by Martin Zimmerman, professor at Michigan Ross. The program featured speakers from sponsor organizations - Marci Carris from Sprint and Todd Strauss from PG\&E - and from universities - Stacey Kole, deputy dean for the full-time MBA program at Chicago School of Business, University of Chicago, and M.S. Krishnan, associate dean at Michigan Ross. Important takeaways from the corporate representatives were numerous. First, they talked about how these findings were being absorbed and understood by sponsors, but over a number of years. The findings were typically not adopted right away. Second, they discussed that many of the real explorations were focused not on their key work but on ideas that are on the periphery. These are the new opportunities that they seek to devote more time to explore in the years to come. The university speakers focused on the need to promote student understanding for communication and teamwork skills. This is especially true as action learning operates in a less controlled environment than traditional 
Ticker: The Academic Business Librarianship Review, 1:1 (2015)

\section{(C) 2015 Corey Seeman}

case studies. The faculty also need to continually assess the scope of the project, so the students have a manageable project to work on.

The other session on the last day of the conference, "Lifelong Action Learning," was moderated by Paula Caproni, lecturer at Michigan Ross. During this session, two alumni members who had action learning as part of their education, along with Dean Eisner, former president and CEO of Manheim, and Eric Hirst, associate dean at the McCombs School of Business, University of Texas at Austin, talked about what the action learning experience meant for their future success in business. Eisner talked about the value of being able to apply what students learned in school in real world settings something that was better found in students who had action-learning experiences. Hirst introduced some results from an assessment survey given to Michigan Ross and Texas McCombs School of Business students on their action learning experience, especially as it relates to their career post-business school. This was an initial assessment of the data and will be expanded and fully explored in the future. Both students were excellent and showcased how the action learning experience helped them in subsequent years in their career. Michigan Ross alum Andrew Burgess talked about how his MAP project and Tauber internship helped immeasurably by providing a safe environment for uncertain learning opportunities. It is through MAP and Tauber projects that students learn as they go - skills that are in play as they move forward in their careers. Michael Phillips, Michigan Ross BBA and Chicago MBA alum, talked about the skills learned in Chicago's Lab program at Chicago
Booth and how the "real" nature of the work he was doing was better than the controlled work done in the classroom.

This was an excellent conference that showcased the role that action learning may play in improving business education. From the library point of view, action learning is a tremendous opportunity for the library to showcase their value in supporting the information needs of students in these projects. If librarians take on roles to help with guides, or serve as embedded librarians, they will be able to make a lasting contribution to the overall success of these action learning programs and the educational mission of the school. A number of faculty were excited about building a research agenda around action learning practice and assessment. This will be interesting to monitor over the next few years.

\section{References}

Berdish, Laura, and Corey Seeman. 2012. Kresge library's embedded librarian program: A student-centered approach. In Embedded librarians: Moving beyond one-shot instruction, 153-164Association of College and Research Libraries Chicago. . 2010. A reference-intensive embedded librarian program: Kresge business administration library's program to support action-based learning at the ross school of business. Public Services Quarterly 6 (2-3): 208-24.

Juricek, John Eric. 2013. Embedded in shanghai: A librarian accompanies students to china. College \& Research Libraries News 74 (3) (March 01): 123-6. 